\title{
Risk Factors for Psychosocial Disorders in Children with Congenital Adrenal Hyperplasia during the COVID-19 Pandemic
}

\author{
Muhammad Faizi(D), Nur Rochmah*(D), Irwanto Irwanto(D), Irma Soelistiyo (D), Yuni Hisbiyah (D), Rayi Kurnia Perwitasari(D) \\ Department of Child Health, Faculty of Medicine, Universitas Airlangga, Dr. Soetomo General Hospital, Surabaya, East Java, \\ Indonesia
}

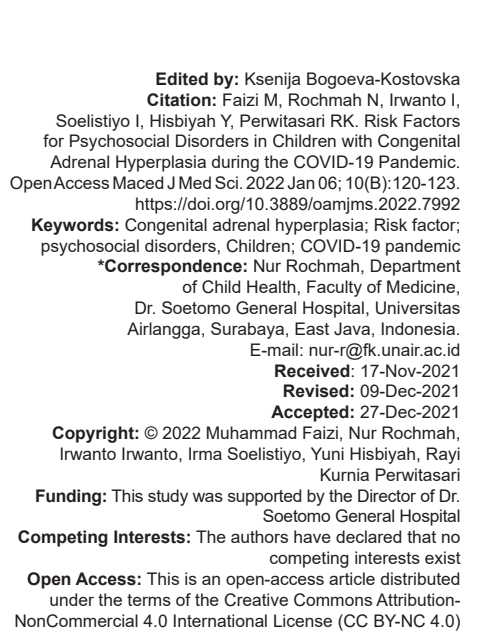

\section{Introduction}

Congenital adrenal hyperplasia $(\mathrm{CAH})$ is a chronic disease that requires lifelong medical therapy; it can possibly cause psychosocial problems such as cognitive disorders, behavioral problems, depressive tendencies, somatic disorders, and attention disorders [1], [2]. Psychosocial problems in children and adolescents are deemed to be quite serious because they negatively impact their development, productivity, and quality of life [3]. In addition to chronic physical illness, psychosocial problems in children and adolescents are also influenced by biological/physical factors, cognitive factors, environment, parental age, parental education, parental occupation, and family income [4].

During the COVID-19 pandemic, there are massive restrictions on social activities, such as schools being conducted online from home. There is limited access to health services and disruption of medicine distribution, thus making it difficult to visit the hospital and take medication regularly. All of these are additional stressors that may worsen psychosocial disorders in children with chronic diseases such as $\mathrm{CAH}[5]$.

Therefore, in this study, we aim to determine the risk factors for psychosocial disorders in children with $\mathrm{CAH}$ during the COVID-19 pandemic. Early detection and intervention for these risk factors have been determined to help prevent psychosocial disorders.

\section{Materials and Methods}

The study population included pediatric patients who had previously been diagnosed with $\mathrm{CAH}$ and underwent outpatient treatment at the Pediatric Endocrinology Outpatient Clinic in Dr. Soetomo General Hospital during the COVID-19 pandemic from January 1 to April 30, 2021. The sampling method used was simple random sampling. Sample size was calculated using Rosner with $\alpha$ of $5 \%$ [6]. The questionnaire used was strength and difficulties 
questionnaire (SDQ) which developed by Goodman with sensitivity of $85 \%$ and specificity $80 \%$ [7]. The SDQ was validated into Indonesian language by Tjhin Wiguna and Yohana Hestyanti in 2005, which consisted of 25 points subdivided in five domains: Emotional symptoms, prosocial behavior, interpersonal relationships, conduct problem symptoms, and hyperactivity [8]. Ethical clearance was obtained from Ethical Committee Board of Dr Soetomo Hospital. Before participating in this study, all respondents given the information for consent orally and in writing. Informed consent was signed by parents who approved to participate in the study and return to researchers. The inclusion criteria in this research were patients aged 3-17 years. The exclusion criteria were $\mathrm{CAH}$ patients who were critically ill or receiving intensive care at the pediatric intensive care unit, patients with a nuclear family history (father/mother/ siblings) of mental disorders, and patients who regularly used psychotropic drugs. The independent variables were father's age, mother's age, father's education level, mother's education level, father's occupation, mother's occupation, and family income. The dependent variables were psychosocial problems, emotional problems, conduct problems, hyperactivity, peer problems, and prosocial.

Data were collected through online interview using phone, filling out the SDQ, and some from medical records. Descriptive analysis was conducted to describe the frequency distribution of each variable. Bivariate analysis was performed to determine the relationship between variables, using the Chi-square test with $p<0.05$ to consider as a statistically significant. All statistical analyzes were conducted using software Statistical Package for the Social Science version 17.0.

\section{Results}

The characteristics of $\mathrm{CAH}$ patients are shown in Table 1, while the results of the SDQ are presented in Figure 1. Based on the results of bivariate analysis, family income was found to be significantly correlated to conduct problems $(p=0.032$ and $\mathrm{Cl}=95 \%)$, as well as hyperactivity $(p=0.019$ and $\mathrm{Cl}=95 \%)$. No significant relationship was noted between parental age, parental education, and parental occupation with behavioral disorders and hyperactivity/attention. Parental age, education, occupation, and income had no significant correlations with psychosocial disorders, emotional disorders, and relationship disorders with friends. in Table 1.

The descriptive analysis in this study is shown

The distribution of SDQ results is shown in Figure 1.
Table 1: Patient characteristics

\begin{tabular}{|c|c|}
\hline Characteristics & Value $\mathrm{n}=30(\%)$ \\
\hline \multicolumn{2}{|l|}{ Age } \\
\hline 3-10 years old & $23(76.7)$ \\
\hline 11-17 years old & $7(23.3)$ \\
\hline \multicolumn{2}{|l|}{ Father's age } \\
\hline$<40$ years old & $17(56.7)$ \\
\hline$\geq 40$ years old & $13(43.3)$ \\
\hline \multicolumn{2}{|l|}{$\operatorname{Sex}(n)$} \\
\hline Male & $11(36.7)$ \\
\hline Female & 19 (63.3) \\
\hline \multicolumn{2}{|l|}{ Father's education level } \\
\hline Elementary to high school & $14(46.7)$ \\
\hline Higher than high school & $16(53.3)$ \\
\hline \multicolumn{2}{|l|}{ Father's occupation } \\
\hline Employees & $19(63.3)$ \\
\hline Professional & $11(36.7)$ \\
\hline \multicolumn{2}{|l|}{ Mother's age } \\
\hline$<38$ years old & $13(43.3)$ \\
\hline$\geq 38$ years old & $17(56.7)$ \\
\hline \multicolumn{2}{|l|}{ Mother's occupation } \\
\hline Employed & $8(26.7)$ \\
\hline Unemployed & $22(73.3)$ \\
\hline \multicolumn{2}{|l|}{ Mother's education level } \\
\hline Elementary to high school & $13(43.3)$ \\
\hline Higher than high school & $17(56.7)$ \\
\hline \multicolumn{2}{|l|}{ Family income } \\
\hline$<$ IDR 2 million & $9(30)$ \\
\hline$\geq$ IDR 2 million & $21(70)$ \\
\hline
\end{tabular}

\section{Discussion}

A significant relationship was observed between family income and behavioral disorders in children with CAH. Similarly, an Australian study found a relationship between poor family conditions and worsening mental health in children. Furthermore, Miller (2013) found a significant relationship between family income levels and mental emotional and behavioral disorders $(p=0.010$ and $r=0.40)$. Respondents with low socioeconomic levels were significantly associated with poor mental health in children $(\mathrm{OR}=2.7$ and $\mathrm{Cl}=1.6-4.4)[9],[10]$.

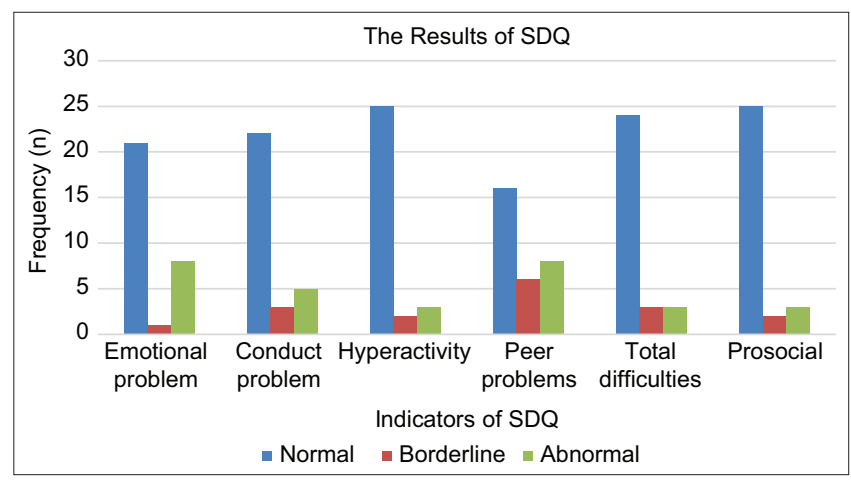

Figure 1: The distribution of SDQ results. SDQ: Strength and difficulties questionnaire

Family income was related with hyperactivity in children with CAH ( $p=0.019)$. In total, 4 children $(44.4 \%)$ from families with below-average income experienced hyperactivity disorders, whereas only $1(4.8 \%)$ out of 21 children from families with aboveaverage incomes had hyperactivity. Thus, children from families with incomes below minimum wage are more likely to experience hyperactivity, whereas those from families with incomes above the minimum wage are not. Mental disorders that are most strongly associated 
with low-income families are hyperactivity and defiant behavior in children, whereas disorders such as anxiety and depressive states have no significant relationship [11].

As per our findings, it was also determined that most of the children (83.3\%) did not experience hyperactivity. The forms of hyperactivity displayed by $\mathrm{CAH}$ children in this study were restlessness, overreacting, inability to stay still for a long time, and constantly moving restlessly and squirming. Nevertheless, most children had good attention spans and were able to complete tasks or homework. If this hyperactive behavior is not handled properly, it could eventually cause obstacles to adjusting social behavior and academic abilities in the home and school environment. As a result, the development of children is not optimal with the emergence of behavioral disorders in the future. This disorder can also hinder the development of language skills. Furthermore, children with hyperactivity may also have difficulty in controlling emotions; they can get frustrated and angry more easily compared with normal children [12].

Out of the 30 children with $\mathrm{CAH}, 8(26.7 \%)$ were found to have experienced emotional disorders. Similarly, studies by Kung and Wiguna, 2010 stated that as many as $42.2 \%$ of children who came for the treatment at the pediatric and adolescent outpatient clinic of Cipto Mangunkusumo Hospital experienced emotional disorders [13]. The forms of emotion reported were nervous feelings or difficulty in parting with parents or caregivers in new situations as well as losing self-confidence easily. The emotional characteristics and patterns described by children included fear, worry, shame, and anxiety. There were also fearful characteristics, such as retreating and withdrawing, as well as imagined pain (i.e., false complaints), such as headaches and stomach pains [14].

There were five children (16.7\%) found to have conduct problems, whereas three children $(10 \%)$ had borderline conduct problems. Often, this manifested as difficulty in controlling anger. The symptoms of children experiencing behavioral disorders included a tendency to intimidate others, fight, use weapons, commit sexual violence, damage the property of oneself and others, start fights, lie, go out at night, run away from home, skip from school, steal, and physically abuse other people or animals. These conduct problems can have a variety of adverse effects on children that can negatively impact them in the future. Conduct problems occurring at a young age are suspected to increase the risk of mental and behavioral disorders in middle age, so it is very important to detect and treat problems as early as possible [15].

Moreover, 8 children (26.7\%) had peer problems, while 6 (20\%) were declared borderline in this aspect. These problems included a tendency to be alone, play alone, and having an easier time in making friends with adults than with other children. This is in line with the theory put forward by Hosokawa, wherein low family income was directly related to conflicts in marriage and parenting practices. This also significantly affected the children's mental health functions, manifesting as impaired social abilities and behavioral problems. On the other hand, high levels of family income are associated with more constructive marital conflict; these are subsequently more widely used in positive parenting practices, resulting in better mental health functioning of children [16], [17].

A family's parenting style affects the emotional development of children. If a child grows up in a family with positive emotions, the child's emotional development will be positive. On the other hand, if the parents express negative emotions, such as venting anger with an aggressive attitude, irritability, disappointment, and pessimism in dealing with problems, then the child's emotional development will be negative [17]. The results of the bivariate analysis showed that no dependent variables were associated with the occurrence of emotional disorders in children with $\mathrm{CAH}$.

Most children with $\mathrm{CAH}(83.3 \%)$ did not experience prosocial behavior problems. In this study, children with younger parents had a greater tendency to experience higher prosocial disorders. This is allegedly related to the ability and experience in educating children. Supposedly, more mature parents would be better at educating their children.

Finally, parents with a higher education level had a higher incidence of prosocial disorders among their children. This contradicts a study in Munich, Germany, mentioning that low parental education is the strongest risk factor for poor mental health in children [10]. The results of this study indicate that none of the dependent variables have a relationship with prosocial disorders in children with $\mathrm{CAH}$.

The limitations of this study are single center and there was no previous data on psychosocial disorders in children with $\mathrm{CAH}$ before the pandemic. Another limitation, this study has not analyzed the correlation of psychosocial disorders and the quality of life. The researchers also declared that there was no conflict of interest in this study.

\section{Conclusion}

Family income is related to behavioral disorders and hyperactivity in children with $\mathrm{CAH}$ during the COVID-19 pandemic. These findings can be taken into consideration for routine screening and early intervention. However, more follow-up research on other factors with a wider population is needed to affirm the results of this study. 


\section{Ethical Clearance}

We sought approval of this research from the Clinical Research Unit of Dr. Soetomo General Hospital Surabaya, Indonesia, as our Ethical Committee Review Board. The ethical clearance was issued by the Clinical Research Unit of Dr. Soetomo General Hospital Surabaya (number 1023/KEPK/III/2019).

\section{Acknowledgments}

The authors would like to thank the patients, families, and pediatric endocrine teams for their time to finishing this study. The authors are also grateful to Director of Dr. Soetomo General Hospital, Surabaya Indonesia Airlangga, Surabaya, Indonesia, for supporting this research.

\section{Author Contribution}

Muhammad Faizi and Irma I. Soelistiyo, designed the study; Nur Rochmah and Yuni Hisbiyah, supervisor on data assessment; Irwanto and Rayi K Perwitasari, responsible for the statistical analysis and publication process. All authors contributed to the literature search and final approval of the version to be submitted.

\section{References}

1. Mathews GA, Fane BA, Conway GS, Brook CGD, Hines M Personality and congenital adrenal hyperplasia: Possible effects of prenatal androgen exposure. Horm Behav. 2009;55(2):285-91. https://doi.org/10.1016/j.yhbeh.2008.11.007 PMid:19100266

2. Liang HY, Chang HL, Chen CY, Chang PY, Lo FS, Lee LW. Psychiatric manifestations in young females with congenital adrenal hyperplasia in Taiwan. Chang Gung Med J. 2008;31(1):66-73.

PMid:18419055

3. Blanchard LT, Gurka MJ, Blackman JA. Emotional developmental, and behavioral health of American children and their families: A report from the 2003 National survey of children's health. Pediatrics. 2006;117(6):e1202-12. https://doi. org/10.1542/peds.2005-2606

PMid: 16740820

4. Prihatiningsih E, Wijayanti Y. Mental and Emotional disorder in elementary School Students [Gangguan Mental Emosional Siswa Sekolah Dasar]. HIGEAI J Public Health Res Dev. 2019;3:252-62.
5. Sayeed A, Kundu S, Al Banna MH, Christopher E, Hasan MT, Begum MR, et al. Mental health outcomes of adults with comorbidity and chronic diseases during the COVID-19 pandemic: A matched case-control study. Psychiatr Danub. 2020;32(3-4):491-498. https://doi.org/10.24869/psyd.2020.491 PMid:33370758

6. Rosner B. Fundamentals of Biostatistics. $7^{\text {th }}$ ed. Boston: Brooks/ Cole, Cengage Learning; 2011

7. Goodman R, Ford T, Corbin T, Meltzer $\mathrm{H}$. Using the strengths and difficulties questionnaire (SDQ) multi-informant algorithm to screen looked-after children for psychiatric disorders. Eur Child Adolesc Psychiatry. 2004;13(Suppl 2):25-31. https://doi. org/10.1007/s00787-004-2005-3

PMid:15243783

8. Goodman R. The strengths and difficulties questionnaire: A research note. J Child Psychol Psychiatry. 2003;38(5):581-6. https://doi.org/10.1111/j.1469-7610.1997.tb01545.x PMid:9255702

9. Miller-Lewis LR, Searle AK, Sawyer MG, Baghurst PA, Hedley D. Resource factors for mental health resilience in early childhood: An analysis with multiple methodologies. Child Adolesc Psychiatry Ment Health. 2013;7(1):6. https://doi. org/10.1186/1753-2000-7-6 PMid:23432929

10. Perna L, Bolte G, Mayrhofer H, Spies G, Mielck A. The impact of the social environment on children's mental health in a prosperous city: An analysis with data from the city of Munich. BMC Public Health. 2010;10:199.

11. Petresco S, Anselmi L, Santos IS, Barros AJ, Fleitlich-Bilyk B, Barros FC, et al. Prevalence and comorbidity of psychiatric disorders among 6-year-old children: 2004 pelotas birth cohort. Soc Psychiatry Psychiatr Epidemiol 2014;49:975-83. https://doi. org/10.1007/s00127-014-0826-Z PMid:24488152

12. Buitelaar J, Arga P. Attention Deficit Hyperactivity Disorder [Gangguan Pemusatan Perhatian dan Hiperaktivitas]. Jakarta: Prenada; 2008.

13. Kung KT, Spencer D, Pasterski V, Neufeld SA, Hindmarsh PC, Hughes IA, et al. Emotional and behavioral adjustment in 4 to 11-year-old boys and girls with classic congenital adrenal hyperplasia and unaffected siblings. Psychoneuroendocrinology. 2018;97:104-10. https://doi. org/10.1016/j.psyneuen.2018.07.004 PMid:30015005

14. Wiguna T, Manengkei PS, Pamela C, Rheza AM, Hapsari WA Emotional disorder and behavior in children and adolescents in RSUPN dr. Ciptomangunkusumo (RSCM) [Masalah Emosi dan Perilaku pada Anak dan Remaja di Poliklinik Jiwa Anak dan Remaja RSUPN dr. Ciptomangunkusumo (RSCM)], Jakarta. Sari Pediatr. 2010;12:270-7.

15. Alves DE, Roysamb E, Oppedal B, Zachrisson HD. Emotional problems in preadolescents in Norway: The role of gender, ethnic minority status, and home- and school-related hassles. Child Adolesc Psychiatry Ment Health. 2011;5(1):37. https://doi. org/10.1186/1753-2000-5-37 PMid:22093180

16. Hosokawa R, Katsura T. A longitudinal study of socioeconomic status, family processes, and child adjustment from preschool until early elementary school: The role of social competence. Child Adolesc Psychiatry Ment Health. 2017;11:62. https://doi. org/10.1186/s13034-017-0206-z PMid:29270216

17. Finkenauer C, Engels RC, Baumeister RF. Parenting behaviour and adolescent behavioural and emotional problems: The role of self-control. Int J Behav Dev. 2005;29(1):58-69. https://doi. org/10.1080/01650250444000333 